\title{
SEROCONVERSION AND SEROREACTIVITY PATTERNS OF DAIRY GOATS NATURALLY EXPOSED TO CAPRINE ARTHRITIS-ENCEPHALITIS VIRUS IN BRAZIL
}

\author{
SOROCONVERSÃO E SOROREATIVIDADE DE CABRAS \\ LEITEIRAS NATURALMENTE EXPOSTAS AO VIRUS DA \\ ARTRITE-ENCEFALITE CAPRINA NO BRASIL
}

\author{
Roberto Soares Castro ${ }^{1}$ Rômulo Cerqueira Leite ${ }^{2}$ Edisio Oliveira de Azevedo $^{3}$ \\ Maurício Resende $^{4}$ Aurora Maria Guimarães Gouveia ${ }^{2}$
}

\section{SUMMARY}

A labelled avidin-biotin ELISA (lab-ELISA) using repeated serum samples of goats showed a progressive seroconversion with higher seroconversion rate at the period going from the beginning of the breeding up to the last half of lactation (35.0\%), compared to that recorded at the beginning of breeding $(17.8 \%)(p<0.05)$. Furthermore, the seroreactivity pattern, evaluated by a lab-ELISA standard-curve with serum samples collected at 30-40 days intervals during 12 months, was caracterized by high individual variability. No seroreversion was observed and there were higher titers in the group of animals which delivered kids and established a lactation period ( $n=6$; mean titre $=913.4$ units) compared to the group of goats that failed to conceived ( $n=4$; mean titre $=261.2$ units) $(p<0.01)$.

Key words: goat; caprine artrhitis-encephalitis virus, diagnostics, enzyme immunoassays, immunity

RESUMO

\begin{abstract}
Foram realizados exames sorológicos em cabras leiteiras, utilizando-se ELISA marcado com avidina-biotina (LAB-ELISA). Esses exames mostraram soroconversão progressiva, com uma taxa maior entre os animais a partir do início da reprodução até a última metade da lactação (35\%) comparada à observada nos animais até o inicio da reprodução $(17,8 \%)(p<0,05)$. Além disso, o padrão de sororeatividade das amostras colhidas a cada 30-40 dias, durante 12 meses, avaliado pelo LAB-ELISA, foi caracterizado por alta variabilidade individual. Não foi observada sororeversão, e títulos mais altos
\end{abstract}

foram obtidos mais no grupo constituido por animais que entraram em lactação $(n=6$, média de títulos $=913,4)$ do que no grupo constituído por animais que cruzaram, mas não conceberam $(n=4$, média de títulos $=261,2)(p<0,01)$.

Palavras-chave: caprino; artrite-encefalite caprina; diagnóstico; imunoensaio enzimático; imunidade; vírus.

\section{INTRODUCTION}

Caprine arthritis-encephalitis (CAE) is a chronic and progressive viral disease of goats characterized by persistent infection, with inflammatory and degenerative lesions of joints, mammary gland, lungs and, less frequently of the nervous system of kids (NARAYAN \& CORK, 1985; NARAYAN et al., 1997). The aetiological agent, caprine arthritis-encephalitis virus (CAEV) included in the retroviridae family, is almost worldwidely distributed, mainly affecting goats from countries where the dairy industry is well developed (ADAMS et al., 1984). In Brazil, the epidemiological surveys have showed a high prevalence of seroreactivity in purebred animals (SARAIVA NETO et al., 1995; CUNHA \& NASCIMENTO, 1995) but it is very low in crossbred goats (CASTRO*, personal observation).

${ }^{1}$ Professor Adjunto, Dr., Universidade Federal Rural de Pernambuco, Departamento de Medicina Veterinária. Rua: Doutor Manoel de Medeiros, s/n , Dois Irmãos, 52171-900, Recife, PE. E-mail: rscastro@ufrpe.br. Autor para correspondência.

${ }^{2}$ Professor Adjunto, Dr., Escola de Veterinária, Universidade Federal de Minas Gerais (UFMG).

${ }^{3}$ Professor Assistente, MSc., Campus VII/ Universidade Federal da Paraíba.

${ }^{4}$ Professor Adjunto, PhD., ICB, UFMG. 
The susceptible animals may be usually infected by oral exposure to CAEV (through the ingestion of infectious colostrum and milk) and less frequently by contact, intramammary route, and from doe to fetus, either prior to, or during the birth process (ADAMS et al., 1983; EAST et al., 1993; LERONDELLE et al., 1995). After CAEV infection, the seroconversions may occur in different periods; some animals present a delayed seroconversion, mainly after the first parturition (RIMSTAD $\boldsymbol{e t}$ al., 1993). Experimentally infected animals produce specific antibodies that reach a maximum level between 49 to 77 days post-infection, and then fall to lower stable titres (ADAMS et al., 1980). Moreover, seroreversion was observed in some naturally infected animals (ROWE et al., 1992; RIMSTAD et al., 1993).

The hormones are responsible for the mammary gland development and lactation maintenance. It has been demonstrated that some hormones are able to activate or to increase the replication rate of retroviruses (LERONDELLE $\boldsymbol{e} t$ al., 1995). In seropositive naturally infected goats, it has been observed an increase in CAEV replication, during hormonal induction of lactation by stradiol, progesterone and hydrocortizone treatment (ASSO et al., 1990).

Considering the particular role of does in CAEV epidemiology and the reports indicating relationship between physiological status and CAEV expression that might interfere in the immunological response, this research work was designed to evaluate the seroconversion and the pattern of seroreactivity of dairy goats naturally exposed to CAEV.

\section{MATERIAL AND METHODS}

\section{Animals}

Seventy three same-generation goats (61 Saanen and 12 Toggenburg breeds) from a CAEVpositive commercial flock, in Minas Gerais State, Brazil, comprising nearly 450 animals, were used to evaluate the seroconversion pattern. At birth the kids were separated from their mothers as soon as possible, and received pasteurized colostrum, followed by non-pasteurized goat milk until 90 days old. They were, then, submitted to an intensive management, feeding on napier grass, corn silage, sugar cane stems, mineral salts and protein concentrate, according to their respective nutritional needs. At about 12 months, they were submitted to a non-hormonal estrous programming, consisting of an artificial 4-hours increase in the daily photoperiods, and were mated by CAEV seronegative fertile bucks. Ten seropositive animals, at the first set of tests, were segregated and used to evaluate the pattern of seroreactivity.

\section{Serology}

The goat sera were obtained by blood centrifugation, and were stored at $-20^{\circ} \mathrm{C}$, until the test performance by the labelled avidin biotin ELISA-lab-ELISA (CASTRO $\boldsymbol{e}$ al., 1999). Briefly, to perform the lab-ELISA, the control and the test sera were dispensed in microplates previously coated with CAEV antigens; a rabbit immunoglobulin $\mathrm{G}(\mathrm{IgG})$ anti-goat $\mathrm{IgG}$ conjugated with biotin (GIBCO-BRL, USA) was added, and after incubation, streptavidin conjugated with horseradish peroxidase (Sigma, USA) was added; the reaction was detected by the addition of substrate mixture $\left(\mathrm{H}_{2} \mathrm{O}_{2}\right.$ and o-phenylenediamine, GIBCOBRL, USA) followed by the enzimatic reaction inhibitor $\left(3 \mathrm{NH}_{2} \mathrm{SO}_{4}\right)$; the optical density (OD) was read in a $492 \mathrm{~nm}$ spectrophotometre (EIA Microplate Reader, Sigma, USA). The results were expressed as a percentage of a high positive reference standard, resulting in a uniform and continuous scale of 0-100 percent positivity.

\section{Evaluation of the seroconversion and seroreactivity patterns \\ The seroconversion pattern was} investigated by testing samples from four periods, selected according to the physiological status of the flock: beginning of breeding, end of gestation, first and last half of lactation. During the study both seronegative and seropositive goats were kept under the same management practices. The seropositive animals in the first set of tests were segregated to evaluate the pattern of seroreactivity, and divided into two experimental groups. In the first one $(\mathrm{CPC}=$ complete productive cycle; $\mathrm{n}=6)$, the goats were bred, became pregnant, delivered their kids and followed their lactation period. The second group (IPC=incomplete productive cycle; $n=4$ ) was composed by goats that were bred, but failed to conceive. Ten serum samples, collected 30 to 40 days apart, from each goat, were titrated in duplicate, in a sole microplate, with a fixed dilution (1:50) as reference to a standard titration curve (KURSTAK, 1985, WRIGHT et al., 1993) constructed from a serial twofold dilutions of a strong positive serum inserted into each plate. This standard was arbitrarily defined to contain 6,400 units of anti-CAEV antibodies per $\mu \ell$ (Figure 1). 


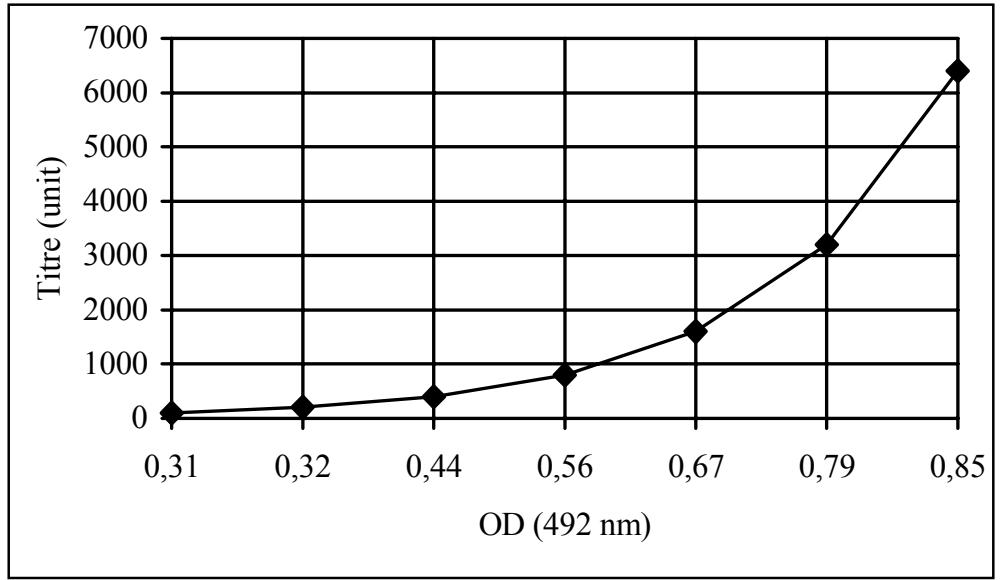

Figure 1 - Lab-ELISA standard unit curve used for the titration of goat serum antibodies against caprine arthritis encephalitis virus.

\section{Statistical analysis}

The seroconversion rates were compared by chi-square, while the serum titres of antibodies against CAEV were analysed by analysis of variance, considering 10 animals, two groups and 10 sampling periods (DEAN et al., 1990).

\section{RESULTS}

Repeated serum samples and testing of goats pointed out a progressive seroconversion pattern with no significant differences among the four studied periods $(\mathrm{p}>0.05)$ (Table 1$)$. However, the seroconversion rate, observed in the period between the beginning of the breeding and the last half of lactation (21/60), was higher than that recorded up to the beginning of breeding $(13 / 73)\left(\mathrm{X}^{2}\right.$ $=6.75 ; \mathrm{p}<0.05)$; the calculated odds ratio (OR) was $0.40(0.17<\mathrm{OR}<0.96)$, and the relative risk $(\mathrm{RR})$ was $0.51(0.28<\mathrm{RR}<0.93)$. The standard curves used to anti-CAEV antibodies serum titration presented a high repeatibility with a mean coefficient of regression of 0.98 . A high individual variability was observed in the titres at both groups (coefficient of variation $=144.6 \%$ ). The titres of antibodies against $\mathrm{CAEV}$, recorded in serum samples from CPC (mean

Table 1 - Seroconversion of 73 dairy goats naturally exposed to caprine arthritis encephalitis virus in Brazil.

\begin{tabular}{lcc}
\hline Physiological status of the flock & Number of seroconversion (\%) & Total seroconversion (\%) \\
\hline Beginning of reproduction & $13(17.8)$ & $13(17.8)$ \\
Ending of gestation & $8(13.3)$ & $21(28.8)$ \\
First half of lactation & $7(13.5)$ & $28(38.3)$ \\
Last half of lactation & $6(13.3)$ & $34(46.6)$ \\
\hline
\end{tabular}

$\mathrm{X}^{2}=0.85(\mathrm{p}>0.05)$
913.4 units), were significantly higher than those from IPC (mean 261.2 units) $(\mathrm{p}<0.01)$ (Figure 2). During the studied period, no seroreversion was observed.

\section{DISCUSSION}

The seroconversion study showed that up to the end of the first productive cycle, almost half of the animals seroconverted, probably due to the use of non-pasteurized goat milk, although the presence of antibodies in the milk was not tested.

The seroconversions occurred during all the studied periods, mainly after breeding. These findings indicate that some susceptible animals seroconverted because of the continued transmission of CAEV, as it has been suggested by ROWE $\boldsymbol{e t}$ al. (1991), and experimentally demonstrated by EAST et al. (1993), probably due to the intensive management and circulation of workers. In CAEV infected flocks, a noteworthy feature is the role of the does, as they are more numerous, and submitted to a lower selection pressure than the bucks; they exert the most important relationship between the newer and the older generations; and they are also submitted to natural periodic hormonal cycles, what should lead to viral expression and transmission (ASSO et al., 1990). Therefore the permanence of seropositive animals in the flock due to the genetic standard favours the maintenance of the infection and the incidence of clinical alterations.

The pattern of seroconversion observed suggests that more emphasis should be placed on testing the new does being selected for breeding and those at the end of their first lactation in CAEV control programmes, it should not underestimate the importance of the transmission among infected and susceptible animals.

The seroreactivity pattern was characterized by a variable individual antibody titre, no seroreversion, and by highest titres in animals with complete productive cycle. This might be a consequence of a complex interaction among animals, viral genotypes and environmental factors. Regarding to the seroreactivity pattern, it must be taken into account that the animals were yearling goats, so it is possible that the titres would be 
stabler after several production cycles in infected animals.

CAEV control is achieved by testing and segregating or culling of seropositive animals together with management practices to prevent the exposure of kids to CAEV (ROWE \& EAST, 1997). All this might favour the selection of virus strains and of animals with low level of humoral immunological-response against CAEV, which might interfere negatively in the control and eradication practices if serological tests are used as the sole criterium to the CAEV infection diagnosis. So, it is our understanding that is necessary more research with newer approaches to explain the relationship among does physiological status and CAEV expression, as well as there is a need of studies on the use of highly sensitive serological tests associated with early viral detection methods such as PCR, in order to identify a higher number of infected animals.

\section{AKNOWLEDGEMENTS}

The authors would like to thank Dr Paulo Ponce de Leon for the review of the manuscript. R.S. Castro is the recipient of a fellowship from Fundação de Aperfeiçoamento de Pessoal de Nível Superior (CAPES). This work was supported in part by Financiadora de Estudos e Projetos (FINEP) and Bem Estar do Menor (Sabinópolis, Minas Gerais).

\section{REFERENCES}

ADAMS, D.S, OLIVER, R.E., AMEGHINO, E., et al. Global survey of serological evidence of caprine arthritis-encephalitis virus infection. Veterinary Record, v.115, p.493-495, 1984.

ADAMS, D.S., CRAWFORD, T.B., BANKS, K.L., et al. Immune response of goats persistently infected with caprine arthritis encephalitis virus. Infection and Immunity, v.28, p.421-427, 1980

ADAMS, D.S., KLEVJER-ANDERSON, P., CARLSON, B.S., $\boldsymbol{e}$ al. Transmission and control of caprine arthritis encephalitis virus. American Journal of Veterinary Research, v.44, p.1670-1675, 1983.

ASS, J, GUIGUEN, F. AND LERONDELLE, C. Induction of the expression of caprine arthritis encephalitis virus in serologically positive animals. Sciences et Techniques de l'Animal de Laboratoire, v.15, p.101-103, 1990.

CASTRO, R.S., LEITE, R.C., RESENDE, M., et al. A labelled avidin - biotin ELISA to detect antibodies to caprine arthritisencephalitis virus in goats' sera. Veterinary Research Communications, n.23, p.515-522, 1999.
CUNHA, R.G., NASCIMENTO, M.D. Ocorrência de anticorpos para o virus da artrite-encefalite caprina em soros de caprinos do Estado do Rio de Janeiro. Revista Brasileira de Medicina Veterinária, v.17, p.72-75, 1995.

DEAN, A.G., DEAN, J.A. AND BURTON, A.H. Epi info, version 5: A word processing, data base, and statistic program for epidemiology on micro-computers. Atlanta, Georgia, : Centers for Disease Control, 1990. 367p.

EAST, N.E., ROWE, J.D., DAHLBERG, J.E., et al. Modes of transmission of caprine arthritis-encephalitis virus infection. Small Ruminant Research, v.10, p.251-262, 1993.

KURSTAK, E. Progress in enzime immunoassays: production of reagents, experimental design, and its interpretation. Bulletin of the World Health Organization, v.63, p.793-811, 1985.

LERONDELLE, C., GREENLAND, T., JANE, M., et al. Infection of lactating goats by mammary instillation of cellborne caprine arthritis-encephalitis virus. Journal of Dairy Science, v.78, p.850-855, 1995.

NARAYAN, O., CORK, L.C. Lentiviral diseases of sheep and goats: Chronic pneumonia, leukoencephalomyelitis and arthritis. Reviews of Infectious Diseases, v.7, p.8997, 1985.

NARAYAN, O., JOAG, S.V., CHEBLOUNE, Y., et al. Visnamaedi: the prototype lentiviral disease. In: NEAL NATHANSON et $\boldsymbol{a l}$. (eds). Viral pathogenesis, Philadelphia: Lipincott-Raven, 1997. p.657-668.

RIMSTAD, E., EAST, N.E., TORTEN, M., et al. Delayed seroconversion following naturally acquired caprine arthritisencephalitis virus infection in goats. American Journal of Veterinary Resesearch, v.54, p.1858-1862, 1993.

ROWE, J.D., EAST, N.E. Risk factors for transmission and methods for control of caprine arthritis-encephalitis virus infection. Veterinary Clinics of North America: Food Animal Practice, v.13, p.34-53, 1997. 
ROWE, J.D., EAST,N.E., THURMOND, M.C. Risk factors associated with caprine arthritis-encephalitis virus infection in goats on California dairies. American Journal of Veterinary Research, v.52, p.510-514, 1991.

ROWE, J.D., EAST,N.E., THURMOND, M.C. Cohort study of natural transmission and two methods for control of caprine artrhitis-encephalitis virus infection in goats on California dairy. American Journal of Veterinary Research, v.53, n.12, p.2386-2394, 1992.
SARAIVA NETO, A.O, CASTRO, R.S, BIRGEL E.H., et al. Estudo soro-epidemiológico da artrite-encefalite caprina em Pernambuco. Pesquisa Veterinária Brasileira, v.15, p.121124,1995

WRIGHT, P.F., NILSSON, E., VAN ROOIJ, E.M.A., et al. Standardisation and validation of enzyme-linked immunosorbent assay techniques for the detection of antibody in infectious disease diagnosis. Revue Scientifique et Technique Office International des Epizooties, v.2, p. 435$450,1993$. 